
СAВРЕМЕНОГ СВЕТА

\author{
Станимир Ђукић \\ Министарство унутрашњих послова Републике Србије
}

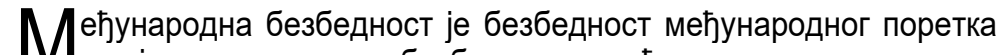
и заједнице, односно безбедност у међународним односима и регионима. Своди се на безбедност држава које су чланице међународне заједнице, а тиме и на безбедност њихових конститутивних елемената, пре свега, човека. Од понашања и стања безбедности држава зависе безбедност других држава, међународна и глобална безбедност. У раду је изведена класификација безбедности и дефинисана међународна безбедност. У раду се разматра примена силе у међународним односима, односно традиционални и савремени концепти међународне безбедности. Такође, у раду се разматрају међународне организације и безбедност у свету, анализирањем основних институција система колективне безбедности, као што су: Организација Уједињених нација (ОУН) и Организација за европску безбедност и сарадњу (ОЕБС). Анализирани су и најпознатији механизми колективне одбране, и то: НАТО и Организација Америчких Држава. С тим у вези, у постојећим условима ОЕБС, ЕУ и НАТО кључни су елементи европске безбедносне архитектуре. Осим тога, разматрани су савремени међународни војно-политички односи и безбедност.

Кључне речи: држава, међународна заједница, безбедност, међународна безбедност, национална безбедност, међународне организације, глобална безбедност, међународни односи

\title{
Увод
}

Д анас, динамиком развоја међународних односа, већи значај у изградњи унутрашње и међународне безбедности имају политички, економски, техничкотехнолошки, социјални, културни и други фрактори. Држава је један од доминантних субјеката међународних односа и међународног права, а тиме и међународне и глобалне безбедности. Уз то, безбедност државе је збирно стање њене тзв. унутрашње и спољне безбедности, као и стање безбедности на међународном нивоу.

Државе су често суочене с дилемом: национална или међународна безбедност? Иако је значај оба нивоа безбедности неспоран за државу и друштво, мало је веро- 
ватно да ће нека држава занемарити сопствене вредности, интересе и безбедност за рачун вредности, интереса и безбедности међународне заједнице или региона. Пре је могуће говорити о извесном делимичном самоограничавању државе у погледу њиховог достизања и безусловне заштите, у ситуацијама када би то могло да угрози друге државе или међународну заједницу.

Суштина међународне безбедности је, као што смо нагласили, трагање за безбедношћу међународног поретка и заједнице, односно за безбедношћу у међународним односима и регионима. Она се, у крајњем случају, своди на безбедност држава које су чланице међународне заједнице, а тиме и на безбедност њихових конститутивних елемената, пре свега, човека. Од понашања и стања безбедности држава зависе безбедност других држава, међународна и глобална безбедност, и обрнуто.

Проблем спољне безбедности земаља, односно стање њихове угрожености, може се посматрати и са становишта припадности те земље организованој међународној заједници, односно положаја и утицаја те земље у тој заједници. Наиме, два светска рата, као и мноштво локалних ратова и војних интервенција, изискивали су од међународне заједнице организовање институционализованог система међународне безбедности (колективне и појединачне), који би се бавио проблемом очувања светског мира. Систем колективне безбедности оличен, у првом реду, у институцији Уједињених нациja (УН), настојао је да уреди односе међу државама чланицама на пољу безбедности на основама међународног права, декларисаном у Повељи Уједињених нација. Припадајући УН све земље (без обзира на свој актуелни однос), прилагодиле су своје понашање на међународном плану начелима и принципима израженим у документима УН.

Приступањем Уједињеним нацијама савремене државе су постале свесне да се одричу дела свог суверенитета у унутрашњим и међународним поступањима због свог, али и због међународног мира. Ограничавање суверенитета сразмерно је власти међународне заједнице на пољу безбедности, чиме се доприноси очувању успостављене међународне безбедности. Државе на тај начин, осим међусобне (билатералне), остварују сарадњу и преко организованог међународног механизма чиме је свакој земљи признато једнако право на одбрану и заштиту свог друштва.

Међутим, многобројни ратови и други акти агресије, као и последњи догађаји са распадом бивше СФРЈ и агресијом НАТО снага на СРЈ, показују да се проблем безбедности међународне заједнице не може решавати без нових момената и решења у сарадњи међу државама у којима се искључује право јачег и примена различитих аршина и тумачења стварности. У супротном, остаје отворено питање не само ефикасности међународног позитивног права и система безбедности, већ се отвара и питање у којој мери међународна заједница уопште може доследно и једнако према свима да примени важеће међународно право и непристрасно да управља међународним системом колективне безбедности.

\section{Класификација безбедности}

Примењујући научни приступ изучавању проблематике безбедности, треба извести класификацију, тј. рашчланити безбедност на врсте, како би се квалитативном анализом делова безбедности остварила научна идентификација безбедности 
као опште вредности савременог света. Уважавајући научни приступ, безбедност се дели на унутрашњу (индивидуална, социјетална и национална) и мећународну (регионална, глобална, заједничка, колективна и кооперативна) безбедност. ${ }^{1}$

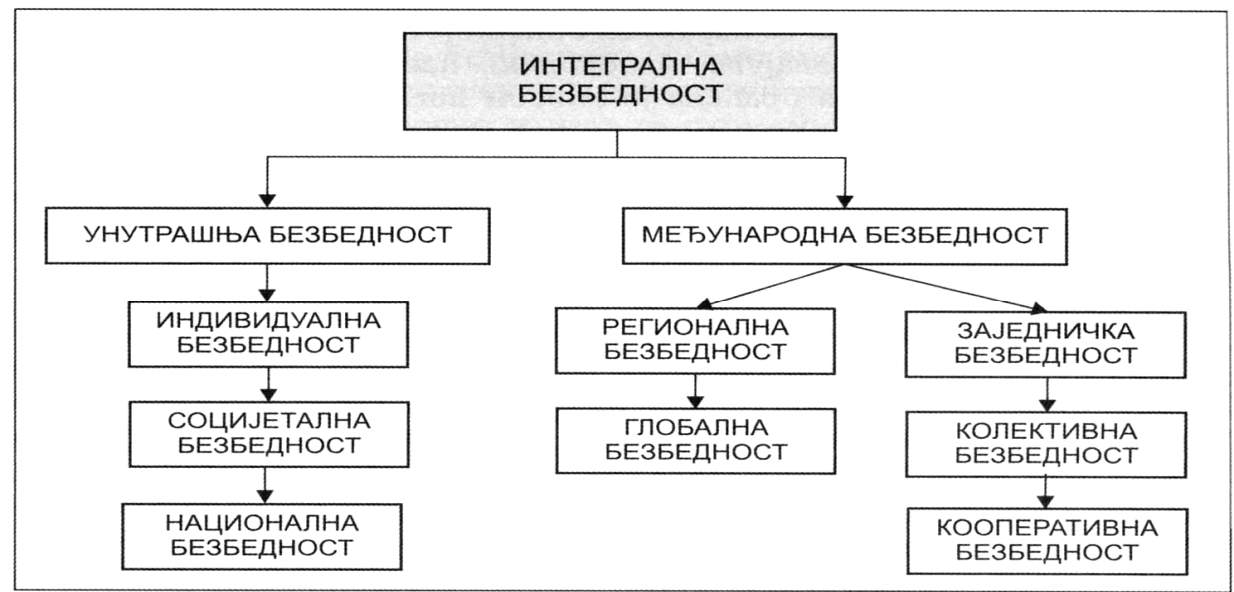

Слика 1 - Класификација безбедности

(Извор: аутор, према: Стајић, Љ., 2011).

Интегрална безбедност се дефинише као свеукупна или целовита безбедност. Представља сублимат унутрашње и међународне безбедности, али не као прости збир тих двеју безбедности, већ као нова вредност која се штити. Не можемо говорити о било каквој, па ни унутрашњој ни међународној безбедности ако је било који елемент тих безбедности значајније угрожен. Као свеобухватна, интегрална безбедност је једна и јединствена и са тог становишта је недељива. Њена подела на унутрашњу и међународну је условна више из педагошких и практичних разлога због лакшег објашњења и учења. Пошто се савремене државе, данас, нападају на свим пољима (породица, вера, власт, уставно уређење, спољна политика, економија, систем безбедности итд.) онда и држава мора свим својим снагама да се супротставља тим нападима. Интегрални напад тражи интегралну одбрану.

Унутрашња безбедност се састоји од индивидуалне, социјеталне и националне безбедности од којих су свака за себе посебне вредности које се штите како системом безбедности тако и другим друштвеним мерама (Ђукић, С., 2017:10).

\section{Међународна безбедност}

Међународна безбедност се може пратити још од периода обликовања првих територијалних заједница људи - племена. Први писани документ који сведочи о регулисању односа између држава датира још од 3100 године п.н.е. Ради се о пи-

\footnotetext{
${ }^{1}$ љ. Стајић, Р. Гаћиновић: Увод у студије безбедности, Драслар партнер, Београд, 2007, стр. 35.
} 
саном уговору (на каменом споменику) којим се регулишу границе између два месопотамска града - државе Логома и Уме. ${ }^{2}$

Међународна безбедност је безбедност међународног поретка и заједнице, односно безбедност у односима држава и међународним регионима. Промишљања о овом нивоу анализе заснована су на потреби да се стабилизују, контролишу и учине безбедним анархични међудржавни односи, који су продукт немогућности контролисања развоја моћи и примене силе, односно регулационих немоћи међународних институција. Њега су узроковале државе асиметричне политичке, економске и војне моћи које настоје да остваре међусобно опречне интересе. Може да се посматра на планетарном (планетарна, светска безбедност), континенталним (континентална безбедност) и на регионалним нивоима (регионална безбедност). ${ }^{3}$

С тим у вези, како наводи Стајић, Љ., „међународну безбедност можемо дефинисати као свеукупно стање међународних односа у којима се сви чланови међународне заједнице осећају безбедним и сигурним и у којима постоје изграђени ефикасни механизми заштите националних држава од свих облика угрожавања и угрожености њихове безбедности".

Регионална безбедност је део међународне безбедности која се фокусира на један регион - пример регион Југоисточне Европе, чији је Србија саставни део. Ризици од избијања ратова и других оружаних сукоба на европском простору знатно су смањени, али нису потпуно отклоњени. То се посебно односи на земље у источној и југоисточној Европи, које су у процесу транзиције суочене са економским, социјалним и политичким проблемима и потешкоћама, што може, у одређеним околностима, да изазове пораст напетости. У постојећим условима ОЕБС, ЕУ и НАТО кључни су елементи европске безбедносне архитектуре. Они су одлучујући фактори у креирању различитих, па и безбедносних односа. Од способности њиховог прилагођавања бројним новим изазовима, константним ризицима и сталним претњама безбедности, као и од карактера односа које ће те асоцијације успостављати са осталим актерима савремене међународне заједнице, највише зависи безбедност евроатланског простора и света у целини (Ђукић, С., 2017:11).

Односи међу државама крећу се од сарадње, преко надметања до сукоба, па се и међународна безбедност увек достизала кроз два модела: конфлликтни (властита безбедност као добро за које се државе надмећу) и кооперативни (властита безбедност као заједнички циљ држава). ${ }^{5}$ Традиционално, примарни предмет међународних односа, међународног права, а тиме и међународне безбедности јесте етиологија и контрола силе као форме међународне комуникације.

\footnotetext{
2 Љ. Аћимовић: Наука о међународним односима, Институт за међународну политику и правду, Београд, 1987, стр. 20.

${ }^{3}$ Опширније, у - Мијалковић, С.: Безбедност државе и концепти међународне безбедности, Дефендологија, број 25-26, Дефендологија центар, Бања Лука, 2009, стр. 69-83. Види и - Keohane, R.: Power and Governance in a Partially Globalized World, Routledge, London - New York, 2002.

${ }^{4}$ љ. Стајић, Р. Гаћиновић: Увод у студије безбедности, Драслар партнер, Београд, 2007, стр. 48.

${ }^{5}$ Таталовић, С.: Национална и међународна сицурност, Политичка култура, Загреб, 2006, стр. 228.

${ }^{6}$ Овакав приступ оправдава „утисак да се у сваком веку, као да је у питању природан закон, појављује једна земља која поседује моћ и вољу, као и интелектуалну и моралну снагу, да у складу са сопственим системом вредности обликује читав међународни поредак, да утиче на међународне односе, уплиће се у унутрашње ствари других држава, намеће сопствене вредности, да се ангажује изван својих граница“. Kissinger, Н.: Дипломатија I, Верзал Прес, Београд, 1999, стр. 5.
} 
Значи, сила је константа међународних односа; променљиви су само њен интензитет и фрорме (отворена или прикривена; војна, политичка и/или економска; непосредна или посредна - посредством трећих актера или на територији трећих земаља; легитимна или нелегитимна, односно легална и нелегална итд). Често „моћније државе“ злоупотребљавају спорне ситуације у међународним односима, „жмурећи пред аргументима и уступцима слабијих“, не би ли нашле поводе да употребом силе реализују сопствене интересе. Осећајући се позваним да се старају о безбедности међународног поретка, инструментализују и заобилазе међународне организације и међународно право, те применом силе наводно спречавају хуманитарне катастрофе које узрокују тзв. недемократски режими. Тако остварују и експлоататорску економску доминацију над слабим земљама које губе свој „економски суверенитет“ (тзв. (нео)империјализам), али и одвраћају пажњу домаће јавности од унутар државних проблема и повећавају национално јединство (тзв. диверзиона теорија рата').

Вођене идејом остваривања својих интереса по сваку цену или бојећи се за свој опстанак, државе често занемарују значај ненасилних метода међународног општења. Најзад, употреба силе као ultima ratio средства за одбрану националних вредности од угрожавања је легална и легитимна. Стога „моћ државе“ може да има хегемонистички (освајајући, субверзивни, агресорски), али и превентивни (одвраћајући), реактивни (одбрамбени, заштитнички) и репресивни (кажњавајући) значај. Очигледно је да се ниво међународне безбедности нужно ослања и надограђује на ниво националне безбедности. Међутим, међународна безбедност није прост збир безбедности држава, као основних субјеката међународне заједнице. Она захтева изградњу извесног система међународних вредности које ће државе и други међународни актери уважавати.

Чињеница да је примена силе у међународним односима била константна у прошлости, наводи нас на закључак да ће је вероватно бити и у будућности. Свесне тога, државе су настојале да је спрече и контролишу, некада тзв. традиционалним, а данас савременим концептима међународне безбедности (Мијалковић, С., 2011:68).

\section{Традиционални концепти међународне безбедности}

Када су у питању традиционални концепти међународне безбедности, може се говорити о равнотежи снага, колективној безбедности, светској влади. Моћ државе је традиционално средство очувања и заштите њених вредности и интереса. Како увећање моћи једне умањује безбедност друге државе, „кључ“ међународне безбедности пронађен је у равнотежи снага - моћи (balance of power), односно у успостављању приближно једнаког односа снага између супротстављених држава или група држава. Оснаживањем држава и савеза „расту и апетити“ за међународним утицајем, што нарушава успостављене равнотеже. Стога практична примена овог концепта није дугорочна, па су потребе за ефикаснијим механизмима међународне безбедности оправдане. Од почетка прошлог века, равнотежа моћи је све чешће критикована, док је колективној безбедности даван све већи значај, нарочито после Другог светског рата.

\footnotetext{
${ }^{7}$ О овој теорији опширније у-Кегли, Ч.В., Виткоф, Ј.Р.: Светска политика - тренд и трансформација, Центар за студије југоисточне Европе, Факултет политичких наука и Дипломатска академија МСП СЦГ, Београд, 2006. стр. 131.
} 
Концепт колективне безбедности (collective security) заснива се на проширеном традиционалном концепту националне безбедности и на извесним међународним уговорима: безбедност земаља уговорница, чије су традиционалне вредности неприкосновене, унапређује се мирним решавањем спорова, колективним (наддржавним) одговором на војне нападе појединих земаља чланица на друге, тако што земљу-агресора застрашују, а земљу-жртву бране, као и колективним одговором на друге безбедносне проблеме које чланице не могу саме да реше. Колективна безбедност је термин који означава договорено, координисано и одрживо стање безбедности унутар групе суверених држава, остварено деловањем заједничког система безбедности. Основне институције система колективне безбедности су: Уједињене нације (УН) и Организација за безбедност и сарадњу у Европи (OSCE) (Ђукић, С., 2017:12). Колективну безбедност треба разликовати од колективне одбране. Реч је о војном савезу суверених држава које су се удружиле ради одбране својих чланица од спољних војних напада (оружане агресије). Државе чланице учествују у колективном војном одговору на оружану претњу или напад који је усмерен према било којој чланици савеза. Најпознатији механизми колективне одбране су HATO и Организација Америчких Држава. ${ }^{8}$ Слично томе, чланице Уједињених нација имају право на колективну самоодбрану (Мијалковић, С., 2011:73).

Кооперативна безбедност је термин који повезује колективну безбедност са општим приступом безбедности. Овај појам најчешће се одређује као „широк приступ безбедности, мултидисциплинарног опсега, који у својој основи фаворизује уверавање у односу на одвраћање; укључивање пре него искључивање; невојна решења у односу на војна; подразумева да су државе првенствени чиниоци система безбедности, али прихвата да недржавни чиниоци могу имати важну улогу; не захтева формално стварање безбедносних установа, али их не искључује и не искључује вредност стваралачке навике дијалога на мултилатералној основи“9 (Ђукић, С., 2017).

У теорији међународних односа временом се дошло до закључка да се сукоби у међународној заједници не могу решити нити превазићи све док се она састоји из великог броја суверених држава које располажу сопственом независном моћи и међу којима владају анархични односи. Сматрало се да такво стање треба заменити образовањем једне снажне средишне установе, која би имала право да доноси потребне одлуке и да их спроводи у дело. То би била влада целог света, организованог као јединствена држава и отуда назив који се даје оваквом систему. Према једном моделу, то би се постигло стварањем неке врсте светске федерације постојећих држава

\footnotetext{
${ }^{8}$ Сваки агресивни акт једне државе против територијалног интегритета или политичке независности било које америчке државе треба сматрати агресивним актом против осталих америчких држава; уколико неповредивост или интегритет територије, или суверенитет или политичка независност једне америчке државе буду угрожени оружаним нападом или неким агресивним актом који није оружани напад, или услед неког ванконтиненталног конфликта или конфликта између две или више америчких држава, или било каквим другим актом или ситуацијом којима би могао да буде доведен у опасност мир Америке, америчке државе, сагласно принципима континенталне солидарности и колективне самоодбране, могу применити мере и поступак који су предвиђени специјалним уговором за такве случајеве. Чланови 27. и 28. Повеље Организације Америчких Држава. Крећа, М.: Исто, стр. 145-146.

${ }_{9}^{9}$ Bruno Simma, Парламентарни надзор безбедносног сектора - Начела, механизми и пракса, Charter of the United Nations, Интерпарламентарна унија и Женевски Центар за контролу оружаних снага, Београд, 2003, стр. 17.
} 
у којем би оне задржале извесну самосталност, али би признале врховништво наддржавних институција, пре свега у области примене превентивних мера и санкција против оних чланица које се не би покоравале основној норми о забрани насилног наметања воље једне државе другој. Други модел је стварање јединствене светске државе која ће заменити и превазићи све постојеће државе и све становнике света довести у непосредну везу са централном влашћу. То би се могло постићи империјалистичким проширивањем власти једне постојеће државе на цео свет његовим покоравањем, или добровољним уједињењем држава. ${ }^{10}$ Иако је ова идеја прогресивна, мало је вероватно да ће овакав концепт икада практично заживети.

\section{Савремени концепти међународне безбедности}

Идеја безбедносног повезивања држава знатно је шира од старе максиме „ако не можеш да га победиш, онда му се придружи“. Њена вредност је у настојању држава да заједнички превазићу традиционална ривалства у анархичним међународним односима и да, достизањем безбедности савеза којим припадају, осигурају и сопствену безбедност: одрицањем или (само)ограничавањем сопствених на рачун заједничких интереса, „улагања држава могу им се вишеструко вратити“. То је суштина идеје заједничке безбедности.

Заједничка безбедност је механизам заснован на сврсисходности замене конкурентности држава због њихове сопствене националне безбедности праксом којом се промовише безбедност свих држава. Безбедност се ефикасније остварује у заједништву, него сопственом моћи ван њега. Прихватање заједничке безбедности као организационог принципа у настојањима смањивања ризика рата, ограничавања у наоружавању и разоружавања значе да ће, генерално, сарадња заменити конфронтацију у решавању конфликата интереса. То не захтева нестанак различитости између нација. Циљ је да конфликтне ситуације не прерасту у рат или у припреме за рат. Стога нације морају да схвате значај светског мира и дају му већи приоритет него одбрани сопствених идеолошких или политичких позиција. На овој идеји засновани су концепти колективне безбедности и одбране, али и безбедносне заједнице, режима, комплекса и сарадње у безбедности ${ }^{11}$ (Мијалковић, С., 2011:74). Заједничка безбедност постоји рецимо, у оквиру Европске уније или Заједнице независних држава - ЗНД. Представници ЕУ тврде да концепт заједничке безбедности и одбране земаља чланица ЕУ није у колизији са концептом колективне безбедности у ОУН, нити са кооперативном безбедношћу и колективном одбраном НАТО. За земље чланице ЕУ, улога ОУН у области међународне безбедности је и даље примарна. За укључивање европских снага у акције очувања мира и безбедности и даље је неопходан мандат ОУН. Такође, и политика европске безбедносне сарадње не доводи у питање трансатланску везу, већ је успостављена политика договарања о употреби заједничких капацитета са НАТО-ом (Ђукић, С., 2017:13).

\footnotetext{
${ }^{10}$ Димитријевић, В., Стојановић, Р.: Основи теорије међународних односа, Службени лист СФРЈ, Београд, 1977, стр. 326-327.

${ }^{11}$ Baylis, J.: Иcmo, стр. 80; Buzan, B., Hansen, L.: Исто, стр. 102-103; Johansen, R. C.: Building World Security: The Need for Strengthened International Institutions, World Security - Chalenges for a New Century (eds. Klare, M. T., Chandrani, Y.), St. Martin`s Press, New York, 1998, p. 387.
} 
Када је у питању глобална безбедност, можемо рећи да је у последњој деценији 20. века дошло до значајних промена у међународној заједници које се огледају у нестанку биполарне поделе света и развоју интеграционих процеса. Развој информационе и комуникационе технологије допринео је интензивирању промена и убрзао процес глобализације скоро свих аспеката међународних односа. У оваквом окружењу сарадња постаје битна претпоставка за јачање мира, стабилности и демократског развоја.

Након завршетка „хладног рата“, а посебно након промене структуре и фуннције НАТО која је уследила на Вашингтонском самиту 1999. године, долази до проширења значења појма безбедности. У научним круговима све више је у оптицају нова појмовна синтагма „глобална безбедност“, као директна последица великих геополитичких промена крајем 20. и почетком 21. века. Ширењем појма безбедности на све аспекте друштвеног живота, он је престао да бива искључиво везан за државу и националну безбедност, а све више се односи на поштовање људских и грађанских права појединаца, дакле на индивидуе као „грађане света“. То је један, у основи, нови футуристички поредак који би требао да уследи као последица економске глобализације света (Стајић, Љ., 2011:36).

Неспорно је да процес глобализације утиче на проширење значења, овог појма на глобалну безбедност, тј. безбедност планете Земље. То је довело до „критичне тачке у односу на редефинисање концепта безбедности, јер не постоји јединствен приступ у дефинисању глобалне безбедности, који би био универзалан и прихватљив“. ${ }^{12}$

Терористички удари на симболе америчке војне, политичке и економске моћи од 11. септембра 2001. године, развили су нову свест о томе да сви људи деле једну планету и чине глобалну заједницу, у којој морају да се уважавају и нека правила како би се могло живети заједно. Основни проблем заједничког живота у глобалној заједници је у томе што су правила глобалне заједнице у интересу великих и моћних држава. Уколико се истински жели остварити глобална безбедност на планети Земљи, онда та правила морају бити фер и праведна (и морају бити схваћена као таква), морају поклонити дужну пажњу сиромашнима, као и моћнима, морају одражавати базично осећање пристојности и социјалне правде. ${ }^{13}$ Управо то није постигнуто садашњим моделом глобализације који снажно захвата и земље у транзицији.

Глобализација је феномен који драматично обележава дух савременог времена и обликује политику, економију и друштвени живот света, мада неједнако и са различитим последицама. Овај универзални процес, који подразумева интензивно економско, технолошко, политичко, идејно-културолошко и војно повезивање људи, народа и држава, по моделу западне цивилизацијске парадигме, добија све више на интензитету, са све израженијом тенденцијом да захвати све сфере индивидуалне и колективне егзистенције људи. Глобална перспектива света и универзализација стандарда свеукупне друштвене организације држава и народа, у њему данас као да је више него извесна. ${ }^{14}$

\footnotetext{
${ }^{12}$ Аврамов, Смиља: Безбедност у 21. веку, Зборник радова СИМБОН 2001. Београд, стр. 426-429.

${ }^{13}$ Stiglic, E. Dzozef: Protivrečnosti globalizacije, SBM-x, Beograd, 2004, стр. 15.

${ }^{14}$ Стојановић Станислав, Безбедност и изазови процеса глобализације, Војно дело бр. 1 из 2005. Београд, стр. 23.
} 
Данас је присутно много дилема које прате феномен глобализације, а једна од основних је: „шта је аутентични смисао глобализације - да ли је она претња свету или шанса за његово значајно поправљање". Односно, да ли ће глобализација свет учинити бољим, ширећи просторе технолошког прогреса, мира, сарадње и демократског развоја људи, народа и држава, или ће, пак, она бити у функцији „афирмације“ принципа моћи, тоталитаризма, неједнакости, насиља и неизвесности, то јест у функцији свих оних тенденција које ће нужно производити подељеност и супротстављеност у свету. ${ }^{15}$

На крају, глобална безбедност је безбедност човечанства од све деструктивнијих изазова, ризика и претњи планетарних димензија којима су непрекидно изложени, а који се могу превазићи само конструктивном сарадњом држава које ће националне интересе подредити човечанским - планетарним. Реч је о концепту који није до краја разрађен и уобличен, али који у центар свог интересовања ставља потребе, вредности и интересе човечанства кроз синтезу међународне безбедности и универзалног нивоа људске безбедности, с нагласком на проблеме савремене економије, квалитета живота, животне средине и оружја за масовно уништавање (Мијалковић, С., 2011:83).

\section{Међународне организације и безбедност у свету}

Иако Комисија за међународно право Уједињених нација није могла да постигне сагласност при дефинисању појма међународне организације, може се рећи да су међународне организације формални институционални облици међународних односа, који се заснивају на добровољној основи. Значи, оне настају на бази сагласности воље суверених држава, али нису супститут државе, већ тела преко којих се остварују заједнички интереси више држава.

Међународне организације, у данашњем смислу, творевина су новијег времена. Настале су из потребе за сарадњом држава на политичком, економском и војном плану. Појавом држава јављају се и одређене противречности које је требало решавати мирним путем или ратом. Многе спорове међу државама требало је решавати преко неког заједничког тела - организације, где би свака држава првенствено задовољила своје интересе, а потом и интересе заједнички удружених држава.

Сазревање свести о потреби међународне сарадње у тесној је вези са економским и технолошким развојем човечанства. Само је низак ниво развитка производних снага допуштао потпуну аутархичност држава. Сваки даљи развој производних снага и вишак материјалних добара био је везан за размену сировина или производа који су се налазили у другим државама. Да би ова размена могла да се обави било је неопходно да се уреде и односи међу државама. Индустријска револуција и са њом повезане друштвене промене оживљавају додире између држава до те мере да им расцепканост билатералне сарадње више не одговара. Сви контакти, сарадња и односи међу државама морали су се уредити по неким законима и правилима. То уређење остваривано је преко међународних организација које омогућа-

\footnotetext{
${ }^{15}$ Исто, стр. 23-24.
} 
вају да државе остану независне, равноправне, да не признају никакву вишу власт, да доносе заједничке одлуке и да обезбеде њихово извршење.

Идеја о међународном организовању имала је своје поборнике још у средњем веку. Они су били обузети жељом да се избегну сукоби између народа или да се уклањањем подвојености између европских држава ојача њихов отпор према противницима изван континента. Њихове идеје довеле су до стварања федерација постојећих држава, које су у својој функцији биле усмерене против могућег противника споља. То се сматра зачетком реализације идеје о колективној безбедности.

Даљи кораци ка стварању међународних организација били су међународни конгреси. Један од значајнијих, Бечки конгрес, одржан 1814. године, надмашио је све раније скупове својим одлукама, али и бројем политичких, социјалних и економских питања којима се бавио.

Поуке Првог светског рата довеле су до стварања прве међународне организације општеполитичке природе, засноване на правилном схватању колективне безбедности. Револуционарна идеја сталне светске организације, повезана са забраном примене силе у односима међу државама и са санкцијама против нападача, нашла је одраз у Друштву народа, основаном 1919. године. Ова организација је стицајем околности остала европска и дуго је била идеолошки искључива. Друштво народа показало се неспособним да очува мир (избио је Други светски рат), па је распуштено 1946. године. Без обзира на слабости, Друштво народа има велики значај за међународно организовање, а као продукт његовог деловања после Другог светског рата фрормира се велики број нових међународних организација (Стајић, љ., 2011:91).

Други светски рат и његове катастрофралне последице упућивали су на неминовност стварања нове универзалне организације. САД и Велика Британија донеле су 14. августа 1941. године Атлантску повељу, у којој су наведена демократска начела будућег мира. Овај документ 1. јануара 1942. године прихвата 26 држава у Декларацији УН, где се назив Уједињене нације први пут званично и употребљава. Декларацију је касније потписала још 21 држава. На Московској конференцији, одржаној 30. октобра 1943. године, Уједињене нације од ратног савеза прерастају у организацију за обезбеђење праведног мира.

Својим формирањем Уједињене нације су успеле да подстакну на оснивање нових и јачање постојећих организација универзалне природе, као што су: Светски поштански савез, Међународна организација за цивилно ваздухопловство, Организација УН за просвету, културу и науку - УНЕСКО, Светска здравствена организација и друге.

После Другог светског рата настаје и регионално политичко организовање у свим деловима света. Тако се, на пример, Арапска лига ствара још пре Уједињених нација. Регионално повезивање држава остварује се у западној Европи, где се 1951. године оснива Европска заједница за угаљ и челик; прва међународна организација са веома наглашеним наддржавним обележјима, по чијем се узору ствара Европска економска заједница (ЕЕЗ) и Европска атомска заједница (Еуратом). У источној Европи оснива се Савет за узајамну економску помоћ (CEВ), који је инструмент тесне економске сарадње и поделе рада између социјалистичких земаља.

У доба хладног рата образује се низ војних савеза, који су у суштини повратак на политику силе и равнотежу снага, али који прихватају искуства међународног организовања, те не остају само на систему уговорних обавеза него стварају чврсте 
војно-блоковске организације с интегрисаним командама и заједничким особљем, као што је то случај са организацијама Северноатлантског пакта (НАТО) и Варшавског уговора (ВУ), који се распао 1991. године.

Афричке земље, ослоњене на заједничке традиције борбе против колонијализма и настале у доба потврде политике несврставања, створиле су своју Организацију афричког јединства.

У свету данас делује више од 230 међународних организација. Предности њиховог постојања и повезивање света све бројнијим и сложенијим нитима изискују оснивање нових. Ера међународних организација, започета пре сто седамдесет година, данас је у пуном замаху.

Из аспекта безбедности наше земље посебно је значајан Европски идентитет безбедности и одбране (ЕИБО), као и међународне организације од утицаја на стање безбедности у Европи.

Осим тога, развијени су и облици међународне полицијске сарадње, чији је основни задатак сузбијање међународног криминала. Субјекти произашли из разних облика међународне полицијске сарадње су многобројни, а најважнији су: Интерпол, Европол и Шенгенски споразум.

Мада су неке међународне организације глобалног карактера а њихово подручје деловања је шире од Европе, оне ће бити обрађене у овом делу, с обзиром на значај њихове улоге у безбедности Европе. То су:

1. Организација Уједињених нација (ОУН);

2. Организација за европску безбедност и сарадњу (ОЕБС);

3. Европска економска заједница (ЕЕЗ);

4. Западноевропска унија (ЗЕУ);

5. Европска унија (ЕУ);

6. HATO;

7. Међународна организација криминалистичке полиције (Интерпол);

8. Уред европске полиције (Европол);

9. Шенгенски споразум (Шенген).

\section{Организација Уједињених нација (ОУН)}

Уједињене нације су званично настале 24. октобра 1945. године, када су Повељу УН ратификовали Кина, СССР, Велика Британија, САД и већина других потписница. Идеја о потреби стварања светске организације сазрела је у току Другог светског рата, када је савез земаља, који се борио против сила Осовине прихватио име „Уједињене нације“ Декларацијом од 1. јануара 1942. године, усвојеном у Лондону. Повељу Уједињених нација саставили су представници 50 земаља. Оне се сматрају чланицама - оснивачима Уједињених нација, али им се придружује још и Пољска, чији је потпис на Повељи стављен касније, јер у доба Конференције није постојала сагласност о томе која је влада овлашћена да је заступа.

Организација Уједињених нација не представља наддржавну творевину, али је ипак субјект међународног права, односно универзална светска организација која повезује све саставне делове међународне заједнице у једну целину. 
Члан 1. Повеље УН:

„Циљеви Уједињених нација су:

1. одржање међународног мира и безбедности и у ту сврху: предузимање ефикасних колективних мера ради спречавања и отклањања претњи миру и сузбијања аката агресије и других повреда мира, као и постизање мирним средствима, а у складу с начелима правде и међународног права, сређивања и решавања међународних спорова или ситуација који би могли довести до повреда мира;

2. развијање међу нацијама пријатељских односа заснованих на поштовању начела равноправности и самоопредељења народа и предузимање других одговарајућих мера ради учвршћења општег мира;

3. постизање међународне сарадње решавањем међународних проблема, економске, социјалне, културне и хуманитарне природе, и унапређивање и подстицање поштовања права човека и основних слобода за све, без обзира на расу, пол, језик или веру;

4. да постану седиште за усклађивање акција предузетих ради постизања ових заједничких циљева“.'

Уједињене нације почивају на идеји колективне безбедности као међународном поретку, који заједничком акцијом свих држава треба да онемогући агресивну политику сваке од њих појединачно. Уједињене нације представљају организацију у којој се утврђује и одлучује да ли постоји напад на неку земљу и усаглашавају заједничке мере против агресора.

Члан 51. Повеље УН гласи:
„Ништа у овој Повељи не умањује урођено право на индивидуалну или колек-
ивну самоодбрану у случају оружаног напада против члана Уједињених нација,
док Савет безбедности не предузме мере потребне за очување међународног ми-
ра и безбедности. О мерама које предузму чланови при вршењу овог права на са-
моодбрану биће одмах извештен Савет безбедности и оне неће ни на који начин
да доведу у питање овлашћење и одговорност Савета безбедности да по овој По-
вељи предузме у свако доба такву акцију ако је сматра нужном ради одржавања и
спостављања међународног мира и безбедности“. ${ }^{7}$

Уједињене нације према усвојеним документима делују у складу са општим начелима савременог међународног права. Та начела су: суверена једнакост чланица, савесно испуњавање обавеза преузетих на основу Повеље, помагање Организацији и забрана мешања Организације у питања која строго задиру у унутрашње надлежности сваке државе. Из посебног карактера УН као оруђа колективне безбедности проистичу забрана употребе и претње силом, дужност решавања спорова мирним путем и овлашћења Организације да настоји да се и нечланице понашају у складу са наведеним начелима, уколико је то потребно ради одржавања међународног мира и безбедности.

Повељом је основано шест органа УН: Генерална скупштина, Савет безбедности, Економски и социјални савет, Старатељски савет, Међународни суд и Секретаријат (слика 2).

\footnotetext{
${ }^{16}$ Радуловић, Б. Р.: Људска права и демократија, Дневник, Нови Сад, 1993, стр. 11.

${ }^{17}$ Исто, стр. 21.
} 


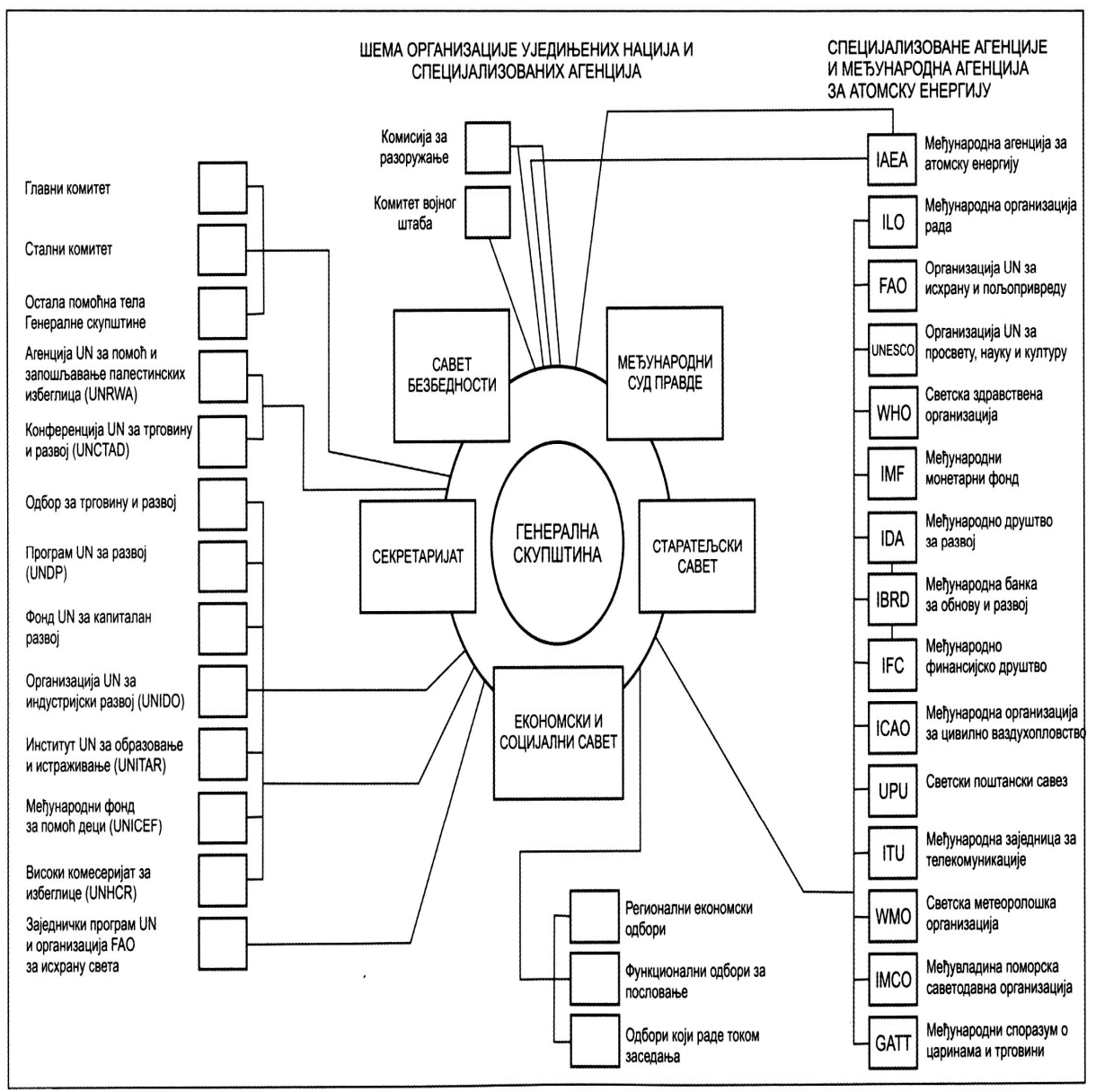

Слика 2 - Шема организације ОУН и специјализованих агенција (Извор: аутор)

Генерална скупштина је главни орган за разматрање међународних проблема и бави се свим питањима у оквиру Повеље, укључујући и она која су у надлежности других органа. Сачињавају је представници свих земаља чланица, а свака од њих има један глас. За одлуке о важним питањима, као што су препоруке о миру и безбедности, пријем нових чланова и буџетска питања, захтева се двотрећинска већина. Одлуке о осталим питањима доносе се простом већином.

Савет безбедности (СБ) сноси примарну одговорност за одржавање међународног мира и безбедности. То је орган који у име УН има право да примењује принуду или да одобри њену примену у међународним односима. Савет има 15 чланова, од којих су 5 стални чланови (Француска, Кина, Русија, Велика Британија и САД), док 10 чланова бира Генерална скупштина на период од две године. Сваки члан Саве- 
та безбедности има један глас. Одлуке о процедуралним питањима доносе се потврдним гласањем најмање 9 од 15 чланова, док се одлуке о суштинским питањима доносе уз пристанак свих пет сталних чланова.

Ово је правило „једногласности великих сила“, које се често назива ветом. Свих пет сталних чланова су, у овој или оној прилици, користили право вета. Ако један стални члан не подржава одлуку, али не жели да блокира ветом, може да се уздржи од гласања. Савет безбедности је једини орган овлашћен да доноси одлуке које су земље чланице обавезне да спроводе у живот.

Међународни суд је главни правосудни орган УН. Његов статут је саставни део Повеље УН. Суд је састављен од 15 судија које бира Генерална скупштина, а седиште му је у Хагу. Надлежност Суда обухвата сва питања која државе пред њега изнесу, као и све случајеве који су предвиђени Повељом УН или уговорима или конвенцијама на снази.

Секретаријат опслужује остале органе УН и спроводи програме и политику коју они утврде. На његовом челу је генерални секретар, кога именује Генерална скупштина по препорукама Савета безбедности.

Уједињене нације, створене као производ релативно високог степена сагласности држава чланица, успеле су да спрече претварање „хладног“ рата у „врући“ и да се међународни односи у већој мери демократизују.

Савет безбедности и ОУН учинили су доста на спречавању и сузбијању сукоба међу државама (1950. године рат у Кореји, сукоб између Израела и Египта од 1956. до 1967. године, затим сукоб у Конгу, на Кипру и сл.).

Под покровитељством ОУН отпочео је процес разоружања, затим решавање колонијалних питања, пружање помоћи земљама у развоју, мере на социјалном плану, хуманитарном плану и друго.

Распадом СССР и распуштањем ВУ, САД постају једина суперсила у свету и као таква она у последње време своје интересе, ставове и одлуке намеће Савету безбедности и ОУН. Према томе, ОУН је све више инструмент политике, а не инструмент држава савременог света и потписница Повеље.

\section{Организација за европску безбедност и сарадњу (ОЕБС)}

Организација за европску безбедност и сарадњу (OSCE) је највећа регионална безбедносна организација на свету, са 55 земаља чланица из Европе, Централне Азије и Северне Америке. Организација је активни носилац функције превенције конфрликата (тзв. рано упозоравање), кризног менаџмента и тзв. постконфоликтне рехабилитације.

Примарне карактеристике ОЕБС-овог деловања на пољу безбедности јесу комбинован приступ превенцији и решавању конфликата и сарадња у реализацији функције безбедности. Комбинован приступ подразумева употребу широког спектра механизама и средстава у одговору на безбедносне изазове, ризике и претње који обухвата: контролу наоружања; превентивну дипломатију; изградњу узајамног поверења између земаља чланица и земаља чланица са другим земљама; унапређење политичких процеса; пројектовање и имплементацију безбедносних мера; промоцију вредности цивилног друштва; промоцију владавине права; заштиту и унапређење људских слобода, права и вредности; демократизацију недемократских поредака и друштава; мисије надгледања парламентарних и председничких избора и других референдума; економску безбедност; еколошку безбедност и дру- 
го. Сарадња подразумева да све земље чланице ОЕБС-а имају равноправан статус и да су одлуке које се доносе на нивоу организације засноване на консензусу.

Начелно, структура и институције ОЕБС-а могу се поделити на форуме за консултације и преговоре и институције за имплементацију и реализацију политичких одлука форума. ${ }^{19}$
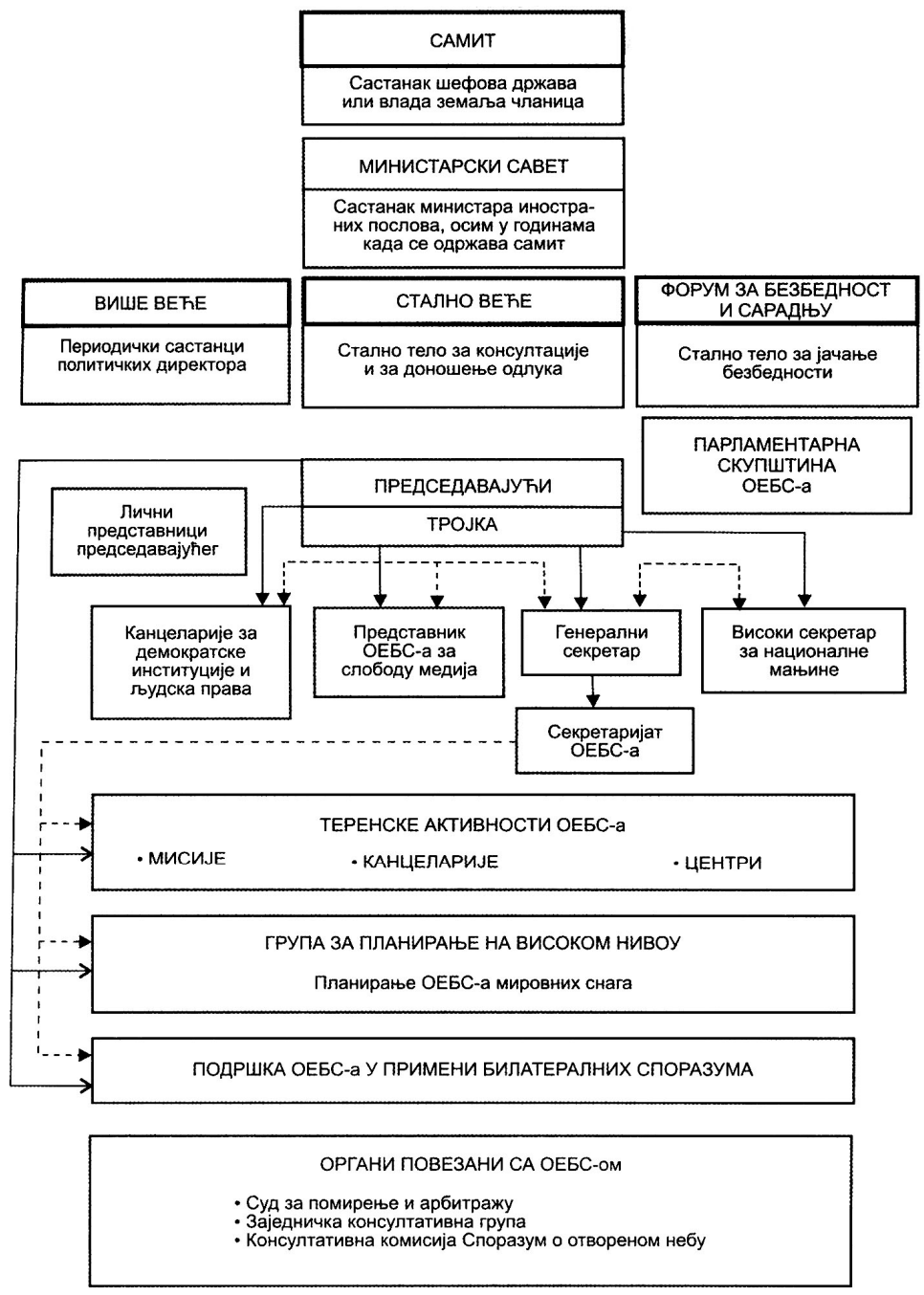

Слика 3 - Структура и институције ОЕБС-а

(Извор: аутор)

\footnotetext{
${ }^{18}$ Види званични сајт ОЕБС-а, www.osce.org.

${ }^{19}$ О организационој структури ОЕБС-а детаљније у: The OSCE Handbook, OSCE, 2000, pp. 21-37.
} 
Организација за европску безбедност и сарадњу лоцирана је у Бечу, с тим што се неке њене канцеларије и институције налазе у Копенхагену, Женеви, Хагу, Прагу и Варшави. У многим земљама налазе се представништва ове организације.

\section{Савремени међународни војно-политички односи и безбедност}

Крајем осамдесетих и почетком деведесетих година XX века наступила је нова епоха у међународним односима. Почетак те епохе означио је завршетак хладног рата и нестанак блоковског надметања и конфронтације, односно прелаз из блоковског система равнотеже војних снага на систем колективне безбедности и процес успостављања „новог светског поретка“.

Уједињење Немачке, претварање ЕЗ у економску, монетарну и политичку унију, са заједничком спољном и безбедносном политиком и елементима заједничке политике одбране, распуштање ВУ, распад Совјетског Савеза на 15 независних и самосталних држава, раздвајање Чехословачке на две самосталне државе, слом система етатистичког „реалног“ социјализма у источноевропским земљама и њихова преоријентација ка Западу, насилна сецесија и разбијање СФРЈ, појачана улога исламског фрактора, појава нових центара економске и политичке моћи, нарастање улоге међународног тероризма и други значајни догађаји, битно су изменили међународне односе и војно-политичку ситуацију у свету.

Тиме је настало ново стање у међународној заједници, чије су основне карактеристике:

- престанак хладног рата;

- нови однос снага моћи и интереса;

- релативизација, неуважавање и злоупотреба међународног права;

- увођење права на војну и другу интервенцију;

- злоупотреба верских заједница и религија у шовинистичко-сецесионистичке сврхе;

- разбијање вишенационалних држава;

- колективна примена силе у форми мултинационалних или коалиционих снага;

- битне промене у ОУН и промена улоге НАТО-а, ЗЕУ и ОЕБС-а у систему колективне безбедности и друго, и

- настајање постмодерног тероризма широких размера.

Најновији међународни односи, а и сама пракса, потврдили су већ изречене тезе, настале после ранијих ратова, да су економске, научно-технолошке, дипломатске, политичке, и психолошко-пропагандне победе некад важније од војних победа, и то не само код малих, већ и код великих народа и земаља. Неки народи, упркос својим ратним победама, историјски су себе поразили у миру, а неки су своје ратне поразе претворили у победу.

Може се рећи да земље Европе и света престају да се деле на победничке и побеђене. Данас у свету настају нови друштвени процеси (цепају се државе, распадају војни блокови, успоставља се потпуна неуравнотеженост односа снага), а творци "новог светског поретка“ кроје нову политичку и економску карту света, користећи методе и средства утицаја са позиције силе, али и ратове (Стајић, Љ., 2011:88). 
Основне претпоставке за грађење нових геополитичких и војно-економских односа у свету данас (посебно у Европи и у региону Средоземља), настале су распуштањем Варшавског уговора (ВУ) и дезинтеграцијом СССР. Развијене земље западног света, пре свега САД, реализовале су стратегијски циљ - елиминисање комунизма као светског процеса. Престао је да постоји биполарни светски поредак, светска ситуација се из основа променила у њихову корист, и оне су дошле у позицију да планирају и наметну тзв. нови светски поредак користећи институције Међународне заједнице. Сједињене Америчке Државе су остале једина глобална суперсила и преузеле су водећу улогу у реализацији тог, још недовољно десринисаног поретка.

Нестајањем биполарно подељеног света отворила се могућност мултиполарности, јер су се појавили неки нови центри економске, геополитичке и војне моћи, са веома различитим националним интересима. Ту се, пре свега, мисли на Немачку у Европи, Јапан, Кину и Индију у Азији и муслиманске државе богате нафтом на Блиском и на Средњем истоку. Свака од тих држава на свој начин сматра себе силом и главним фрактором у региону, чиме би могла да изазове кризу светских размера.

Нови центри моћи решење својих интереса виде у постојању и новом начину функционисања међународних организација. Међународне светске организације и институције већ су постале међународни механизам за остваривање циљева великих држава. Сједињене Америчке Државе и НАТО упорно траже проширење своје зоне одговорности са матичних територија на територију потенцијалног угрожавања интереса и безбедности својих чланица. То значи да, без обзира на све међународне норме и суверена права држава, те државе саме бирају територију „свог“ интереса и процењују своју угроженост.

Оштра сукобљеност интереса великих сила (посебно односи Русије и САД), нарочито у економско-трговинској сфрери, постојећа стара, нова и могућа кризна жаришта и веома сложен процес грађења новог светског поретка око чијег успостављања постоје многобројна неслагања, још не гарантују хармоничне светске односе ни сигуран светски мир. То за мале земље и земље дуге националне традиције, као што је наша, значи потребу одржавања и развоја довољних оружаних снага у оквиру ефикасног и оптималног система безбедности, као гаранта обезбеђивања и реализације сопственог националног интереса, од чега ниједна држава у свету, а поготову велике силе, ни на који начин не одустају.

\section{Закључак}

Уважавајући научни приступ, безбедност се дели на унутрашњу (индивидуална, социјетална и национална) и међународну (регионална, глобална, заједничка, колективна и кооперативна) безбедност.

Међународну безбедност можемо дефинисати као свеукупно стање међународних односа у којима су сви чланови међународне заједнице безбедни и у којима постоје изграђени ефикасни механизми заштите националних држава од свих облика угрожавања њихове безбедности (Ђукић, С., 2017:15).

Међународна и национална безбедност су комплементарне категорије. Иако се могу посматрати независно једна од друге, иако су могуће ситуације у којима угро- 
жена национална безбедност не дестабилизује међународну безбедност и обрнуто, ови феномени су најчешће у односу међуутицаја и међузависности. Спона националне и међународне безбедности су међународно право, међународни односи и међународне организације, односно безбедност људи.

Када су у питању међународне организације, може се рећи да су оне формални институционални облици међународних односа, који се заснивају на добровољној основи. Самим тим, оне настају на бази сагласности воље суверених држава, али нису супститут државе, већ тела преко којих се остварују заједнички интереси више држава.

Међународне организације, у данашњем смислу, творевина су новијег времена, и настале су из потребе за сарадњом држава на политичком, економском и војном плану. У свету данас делује више од 230 међународних организација. Мада су неке међународне организације глобалног карактера, а њихово подручје деловања је шире од Европе, с обзиром на значај њихове улоге у безбедности Европе, набројаћемо најважније, и то: Организација Уједињених нација (ОУН); Организација за европску безбедност и сарадњу (ОЕБС); Европска економска заједница (ЕЕЗ); Западноевропска унија (ЗЕУ); Европска унија (ЕУ) и НАТО. Најпознатији механизми колективне одбране су НАТО и Организација Америчких Држава. Из аспекта безбедности наше земље посебно је значајан Европски идентитет безбедности и одбране (ЕИБО).

Осим тога, развијени су и облици међународне полицијске сарадње, чији је основни задатак сузбијање међународног криминала, а најважнији су: Међународна организација криминалистичке полиције (Интерпол); Уред европске полиције (Европол) и Шенгенски споразум (Шенген).

Данашња динамика развоја међународних односа, посебно процеси глобализације са развијенијим везама између држава и региона, и измењена схватања у области задовољавања националних интереса, све мање зависе од политичких концепата великих сила. У таквим условима већи значај у изградњи унутрашње и међународне безбедности имају политички, економски, техничко-технолошки, социјални, културни и други фактори, па је у будућности свако заснивање међународних односа само на моћи и сили, са аспекта демократских процеса и глобалне безбедности, дубоко превазиђен политички концепт. Полазећи од те чињенице изградња стабилне међународне безбедности треба да буде услов за опстанак и успешан развој држава, и стабилна основа за елиминисање свих конфликата који могу довести у питање стабилност и безбедност националних држава.

\section{Лumepamypa}

[1] Bruno Simma, Парламентарни надзор безбедносног сектора - Начела, механизми и пракса, Charter of the United Nations, Интерпарламентарна унија и Женевски Центар за контролу оружаних снага, Београд, 2003, стр. 17.

[2] Baylis J., International and Global Security in the Post-Cold War Era, The Globalization of World Politics (eds. Baylis, J., Smith, S.), Oxford Press, New York, 2001. pp. 253-276, y: Рефрорма сектора безбедности (ур. Хаџић, М.), Институт Г 17 плус и Центар за цивилно-војне односе, Београд, 2003.

[3] Војин Димитријевић, Стојановић, Р., Основи теорије међународних односа (Београд: Службени лист СФРЈ, 1977). 
[4] Војин Димитријевић, Међународни односи (Београд: Радничка штампа, 1996).

[5] Кегли Ч. В., Виткоф J. Р., Светска политика - тренд и трансформација (Београд: Центар за студије југоисточне Европе, Факултет политичких наука и Дипломатска академија МСП СЦГ, 2006).

[6] Љубивоје Аћимовић, Наука о међународним односима (Београд: Институт за међународну политику и правду, 1987).

[7] Љубомир Стајић, Р. Гаћиновић, Увод у студије безбедности (Београд: Драслар партнер, 2007).

[8] Љубомир Стајић, Основи система безбедности (Нови Сад: Правни факултет, 2011).

[9] Миленко Крећа, Практикум за међународно јавно право (Београд: Полицијска академија, 1997).

[10] Радоје Радуловић, Људска права и демократија (Нови Сад: Дневник, 1993).

[11] Смиља Аврамов, Безбедност у 21. веку (Београд: Зборник радова СИМБОН, 2001).

[12] Stiglic E. Dzozef, Protivrečnosti globalizacije (Beograd: SBM-x, 2004).

[13] Станислав Стојановић, Безбедност и изазови процеса глобализације, Часопис Војно дело, година излажења 67, број 1, (2005).

[14] Синиша Таталовић, Национална и међународна сигурност (Загреб: Политичка култура, 2006).

[15] Станимир Ђукић, Безбедносни менацмент и савремени безбедносни изазови, ризици и претње као угрожавајуће делатности националној безбедности, Часопис Војно дело, година излажења 67, број 8, (2016).

[16] Станимир Ђукић, Основи безбедности и систем безбедности у стратегији националне безбедности, Часопис Војно дело, година излажења 67, број, (2017).

[17] Саша Мијалковић, Безбедност државе и концепти међународне безбедности, Дефендологија, број 25-26, Дефендологија центар, Бања Лука, 2009, стр. 69-83. Види и Keohane, R.: Power and Governance in a Partially Globalized World, Routledge, London - New York, 2002.

[18] Саша Мијалковић, Национална безбедност (Београд: Криминалистичко-полицијска академија, 2011).

[19] Henry Kissinger, Дипломатија I и II (Београд: Верзал Прес, 1999). 